(C) I. A. Tikhonovich, N. A. Provorov

All-Russia Research Institute for Agricultural Microbiology

is The molecular mechanism of the agronomically important nutritional and defensive plantmicrobe symbioses are reviewed. These symbioses are based on the signaling interactions which result in the development of novel tissue/cellular structures and of extended metabolic capacities in the partners which improve greatly the adaptive potential of plants due to an increased tolerance to biotic or abiotic stresses. The molecular, genetic and ecological knowledge on plant-microbe interactions provide a strategy for a sustainable crop production based on substituting the agrochemicals (mineral fertilizers, pesticides) by the microbial inoculants. An improvement of plantmicrobe symbioses should involve the coordinated partners' modifications resulted in complementary combinations of their genotypes.

Key words: beneficial plant-microbe interactions; symbiotic nitrogen fixation, arbuscular mycorrhiza, nodule bacteria, cyanobacteria, ergot fungi, endophytes, biocontrol of pathogens and phytophagans, sustainable plant production

\section{MOLECULAR STRATEGIES AND AGRONOMIC IMPACTS OF PLANT-MICROBE SYMBIOSES}

\section{INTRODUCTION}

Genetic, molecular and ecological research of the beneficial plant-microbe interactions comprises an exiting and swiftly developing field in modern biology. These interactions may be classified into two categories: nutritional and defensive (Table 1). The first category involves: (1) mycorrhizal symbioses responsible for supplying the plants with soil nutrients; (2) nitrogen-fixing symbioses which are most effective in legumes inoculated with rhizobia. The second category is represented by the broad spectrum of endo- and epiphytic associations in which different bacteria and fungi protect their hosts from pathogens or phytophagans.

\section{NITROGEN-FIXING SYMBIOSES}

Being the principle sources of fixed carbon in the majority of terrestrial ecosystems, plants usually suffer a deficiency of nitrogen because they are devoid of nitrogenase enzyme required for $\mathrm{N}_{2}$ fixation: distribution of this enzyme (and of nif genes encoding for its synthesis) is restricted to prokaryotes. This is why many plants balance their $\mathrm{N} / \mathrm{C}$ ratio due to symbioses with different $\mathrm{N}_{2}$-fixing bacteria.

\subsection{Legume-rhizobia symbiosis}

Being highly diverse (17000-19000 globally distributed species), legumes (Fabaceae) in collaboration with rhizobia make the largest contribution into $\mathrm{N}$ balance in natural and agricultural ecosystems (Allen, Allen, 1981). N fixation occurs within the root (sometimes, stem) nodules the formation of which represents the sequential process based on the tightly coordinated expression of the specialized plant and bacterial genes.

\subsubsection{Development and regulation}

The legume-rhizobia interactions vary in the specificity which may be classified into the narrow and broad types (Table 2). The legumes grown in temperate areas (Pisum, Medicago, Lotus, Trifolium) are inoculated by specific groups of $\alpha$-proteobacteria (Rhizobium, Sinorhizobium species close to pathogenic Agrobacterium). Interactions between the tropical legumes and their microsymbionts are less specific: they involve several distant groups of $\alpha$-proteobacteria (including Azorhizobium close to Xanthobacter, and Bradyrhizobium close to Rhodopseudomonas) and some $\beta$-proteobacteria (Balanchadar et al., 2007).

The specificity of interactions is controlled by the lipo-chito-oligosaccharide Nod factors (NFs) the synthesis and functions of which will be addressed by a special paper in this volume (Dolgikh et al., 2008). Here we shall point only that NFs responsible for contrast types of symbiotic specificity have different structures in the acyl chains: narrow specificity is related to poly-unsaturated $(2-4$ double $\mathrm{C}=\mathrm{C}$ bounds per 16-20 $\mathrm{C}$ atoms) while for broad specificity is related to the saturated or mono-unsaturated acyl chains. The signaling processes initiated in plant roots by NFs involve many stages common to plant-pathogen interactions. For example, NFs are recognized by the receptor-like kinases (RLK) containing the LysM domains and afterwards the signal information is transmitted to the internal messengers (Madsen et al., 2003; Radutoiu et al., 2003) including RLK which contain the leucine rich repeats (LRR) being similar to the products of plant $R$-genes responsible for the resistance to pathogens (Michelmore, Meyers, 1998). The signaling cascade induces the early nodulin $(E N O D)$ genes for some of which the products are 
The major types of beneficial plant-microbe interactions

\begin{tabular}{|c|c|c|c|}
\hline $\begin{array}{c}\text { Types } \\
\text { of symbiosis }\end{array}$ & Beneficial impacts on plants & Mechanisms & Best studied symbioses \\
\hline \multirow{4}{*}{ Nutritional } & \multirow{2}{*}{ Supply of nitrogen } & Fixation of atmospheric $\mathrm{N}_{2}$ & $\begin{array}{l}\text { Nodule bacteria (rhizobia) with legumes; } \\
\text { actinomycetes Frankia with some dicots; } \\
\text { filamentous cyanobacteria (Nostoc, Ana- } \\
\text { baena) with diverse land plants }\end{array}$ \\
\hline & & $\begin{array}{l}\text { Extraction of } \mathrm{N} \text { from soils (including } \\
\text { mineralization of organic com- } \\
\text { pounds) }\end{array}$ & $\begin{array}{l}\text { Ectomycorrhizal (EC) fungi (Basidiomy- } \\
\text { cota, Ascomycota) with some angio- } \\
\text { sperms and gymnosperms (mainly, trees } \\
\text { and shrubs) }\end{array}$ \\
\hline & \multirow[t]{2}{*}{ Supply of phosphorous } & $\begin{array}{l}\text { Adsorption of soil phosphates and } \\
\text { their transfer into plants }\end{array}$ & $\begin{array}{l}\text { Arbuscular mycorrhizal (AM) fungi } \\
\text { (Glomeromycota) with } 80-90 \% \text { of } \\
\text { plants }\end{array}$ \\
\hline & & $\begin{array}{l}\text { Extraction of P from insoluble soil } \\
\text { compounds }\end{array}$ & $\begin{array}{l}\text { EC and AM fungi, phosphate solubiliz- } \\
\text { ing bacteria (Bacillus) }\end{array}$ \\
\hline \multirow{2}{*}{ Defensive } & Suppression of pathogens & $\begin{array}{l}\text { Competitive exclusion of pathogens } \\
\text { (e. g., synthesis of antibiotics), induc- } \\
\text { tion of systemic resistance in plants }\end{array}$ & $\begin{array}{l}\text { Plant growth promoting rhizobacteria } \\
\text { (PGPR), p-endophytes (Phialophora, } \\
\text { Gliocladium), mycorrhizal fungi }\end{array}$ \\
\hline & $\begin{array}{l}\text { Suppression } \\
\text { of phytophagans }\end{array}$ & Synthesis of toxins & $\begin{array}{l}\text { Clavicipitacean (ergot) fungi (Ascomy- } \\
\text { cota), gram-positive bacteria (Clavi- } \\
\text { bacter) }\end{array}$ \\
\hline
\end{tabular}

Examples of narrow and broad specificity in the rhizobia-legume interactions

\begin{tabular}{|c|c|c|}
\hline Symbiotic specificity & Rhizobia strains & $\begin{array}{l}\text { Legume hosts (taxonomy is given according to: Allen, Allen, } \\
\qquad 1981 \text { ) }\end{array}$ \\
\hline \multirow{4}{*}{$\begin{array}{l}\text { Narrow (cross- } \\
\text { inoculation groups) }\end{array}$} & Rhizobium galegae & Legumes representing the same genus: Galega \\
\hline & Rhizobium leguminosarum bv. trifolii & Legumes representing the same genus: Trifolium \\
\hline & Rhizobium leguminosarum bv. viceae & $\begin{array}{l}\text { Legumes representing the same tribe of subfamily Papilionoi- } \\
\text { deae: Vicieae (Pisum, Vicia, Lathurus, Lens) }\end{array}$ \\
\hline & Sinorhizobium meliloti, S. medicae & $\begin{array}{l}\text { Legumes representing the same tribe of subfamily Papilionoi- } \\
\text { deae: Trifolieae (Medicago, Melilotus, Trigonella) }\end{array}$ \\
\hline \multirow[t]{4}{*}{ Broad } & 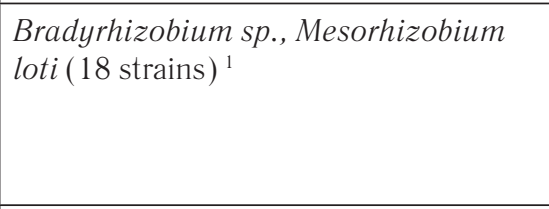 & $\begin{array}{l}\text { Legumes representing different tribes of subfamily Papilionoi- } \\
\text { deae: Galegeae (Astragalus glycyphyllus, Caragana arbore- } \\
\text { scens), Genisteae (Lupinus densiflorus), Hedysareae (Orni- } \\
\text { thopus sativus), Trifolieae (Ononis repens), Loteae (Anthyllis } \\
\text { vulneraria, Lotus corniculatus, L. uliginosus) }\end{array}$ \\
\hline & $\begin{array}{l}\text { Bradyrhizobium japonicum }(102 \\
\text { strains })^{2}\end{array}$ & $\begin{array}{l}\text { Legumes representing different subfamilies of the Fabaceae: } \\
\text { Caesalpinioideae: Cassieae (Cassia nictitans); Papilionoideae: } \\
\text { Genisteae (Crotalaria sagittalis, Genista tinctoria), Hedysare- } \\
\text { ae (Desmodium paniculatum, Lespedeza hirta, L. frutescens), } \\
\text { Phaseoleae (Amphicarpaea bracheata, Dolichos lablab), } \\
\text { Podalyrieae (Baptisia tinctoria), }\end{array}$ \\
\hline & Rhizobium tropici ${ }^{3}$ & $\begin{array}{l}\text { Legumes representing different subfamilies of the Fabaceae: } \\
\text { Mimosoideae: Eumimoseae (Leucaena leucocephala); Papil- } \\
\text { ionoideae: Phaseoleae (Phaseolus vulgaris) }\end{array}$ \\
\hline & Sinorhizobium fredii (strain NGR234) ${ }^{4}$ & $\begin{array}{l}\text { Legumes representing } 112 \text { genera from all three subfamilies of } \\
\text { the Fabaceae as well as the non-legume Parasponia (Ulmaceae) }\end{array}$ \\
\hline
\end{tabular}

${ }^{1}$ Jensen, 1967 (referred as Rhizobium lupini and Rhizobium spp.).

${ }^{2}$ Conklin, 1936 (referred as Rhizobium japonicum).

${ }^{3}$ Brom et al., 1988 (referred as Rhizobium phaseoli, symbiotype 2)

${ }^{4}$ Broughton, Perret, 1999. 
similar to PR (pathogen-regulated) proteins and extensins (Brewin, 2004; Ovtsyna, Staehelin, 2005).

However, the developmental impacts of signaling processes responsible for nodulation are quite different from the pathogenic interactions. In Pisum, Medicago and Lotus species the symbiosis ontogeny starts from the rhizobia penetration into the root hairs leading to their curling and development of the special tunnel structures called infection threads (ITs) (Brewin, 1991). ITs grow inter- and intra-cellularly into the cortex wherein the mitotic reactivation occurs in some cells and the nodule primordium is established which differentiates into several tissue types some of which (located in the centre of emerging nodule) are infected by ITs. Several ENOD genes (e. g., ENOD5, ENOD12) are involved in the IT growth since their products are located in the IT walls (Franssen et al., 1992). This development is culminated in the release of rhizobia into the plant cell cytoplasm where they are surrounded by the host membrane and form the organelle-like symbiosomes (Roth, Stacey, 1989). Inside them, rhizobia differentiate in the bacteroids in which the nitrogense enzyme is synthesized and $\mathrm{N}_{2}$ fixation occurs

At present, nearly all nodulation stages are dissected using the plant mutations arresting IT growth and tissue differentiation. The functional sequence of the involved genes was revealed due to analysis of complementary and epistatic gene interactions in the double mutant lines which combine different developmental mutations (Borisov et al., 1997; Tsyganov et al., 1998). The revealed plant genes are expressed in a tight cooperation with the bacterial symbiotic genes which compose the functionally integrated, super-organism gene network. Its integrity is illustrated by the data demonstrating that similar developmental defects may be obtained due to the plant and bacterial mutations (Provorov et al., 2002; Borisov et al., 2004). Characteristically, the plant $\mathrm{Nod}^{-}$and $\mathrm{Fix}^{-}$mutations usually do not influence the resistance to pathogens, while establishment of the other mutualistic symbiosis, arbuscular mycorrhiza (AM) may be arrested by many of these mutations (Section 3 ).

The major prerequisite for an efficient legume-rhizobia interaction is the very stringent control over the bacterial performance within the root nodules. It starts just at the first steps of invasion when the IT walls isolate the bacterial cells from the cytoplasm of infected root hairs. During IT growth in the epidermis and cortex a range of defenselike reactions are induced including synthesis of phenolics, flavonoids, lytic enzymes and reactive oxygen species (Gamas et al., 1998; Santos et al., 2001; Brewin, 2004). Due to these reactions, nodule development which is quite different from the pathogenic interactions at the organ/ tissue levels, appeared to be similar to them at the cellular/molecular levels. These similarities may be enhanced greatly if the structures of bacterial exopolysaccharides, lipopolysaccharides or cyclic $\beta$-glucans are changed by mu- tations demonstrating that these surface components are responsible for suppressing the host immune responses (Breedveld, Miller, 1994; Niehaus et al., 1998; Kannenberg et al., 1998).

At the very beginning of nodule ontogeny, systemic regulation of nodulation is switched on to balance the symbiosis with the nutritional and energy status of the plant organism (Kinkema et al., 2006). This balance is reached due to the autoregulation of nodulation $(\mathrm{AON})$ induced by a hypothetical signal transmitted from the emerging nodule primordium into the shoots and eliciting the feedback response which prevents formation of the excessive nodules. Mutations in the genes controlling AON lead to a supernodulation $\left(\mathrm{Nod}^{++}\right)$phenotype and the plant biomass can be decreased in spite of an increased total $\mathrm{N}_{2}$-fixing activity (Novak et al., 1997). These mutants are usually able to nodulate effectively under a sufficient nitrate supply leading to Nts (Nitrate tolerant symbiosis) phenotype. Therefore, important function of $\mathrm{AON}$ is to arrest symbiosis when its formation does not lead to an adaptive gain by host. The involved plant genes (e. g., NARK) are close to CLAVATA genes regulating of meristimatic activities and having no homologues among the resistance $(R)$ genes (Beveridge et al., 2007). However, after inducing AON, some processes common to Systemic Acquired Resistance (SAR) are detected in legumes, including salicilate and jasmonate syntheses (Kinkema et al., 2006).

\subsubsection{Nitrogen fixation and assimilation}

Due to cooperation between the legumes and rhizobia, two fundamental processes are combined in the super-organism system: fixation of $\mathrm{N}_{2}$ and of $\mathrm{CO}_{2}$. A highly integrated network of partners' $\mathrm{C}$ and $\mathrm{N}$ metabolic pathways is formed in nodules responsible for acquiring by plant of a novel adaptive property - symbiotrophic nitrogen nutrition. For this, partners fulfill a range of functions responsible for a high efficiency of cooperation: the amount of $\mathrm{N}_{2}$ obtained symbiotically by some leguminous crops (Medicago sativa, Galega orientalis) may reach $550-600 \mathrm{~kg} / \mathrm{ha}$ per season (Provorov, Tikhonovich, 2003).

In order to fuel the energy consuming biochemical machinery in nodules the host should spend up to $30 \%$ of its photosynthesis products. About a half of them is lost for respiration that supplies ATP for nitrogenase and for building the symbiotic structures. Another half is a reversible investment used to assimilate fixed $\mathrm{N}$ and to transport it to the shoots (Phillips, 1980; Vance, Heichel, 1991; Fisher, 1994).

The photosynthesis products supplied to the infected nodule cells are fermented in an unusual way, not to pyruvate but to malate that can be used immediately in the tricarboxylic acid (TCA) cycle in bacterial cells. Malate together with some other $\mathrm{C} 4$-dicarboxylic acids (succinate, fumarate) are up-taken by bacteroids via the DctA permease (Jording et al., 1994). Nearly all ATP produced in bacteroids is used to supply energy to nitrogenase en- 
zyme the immediate product of its which, $\mathrm{NH}_{4}{ }^{+}$is excreted into the host cytoplasm since the enzymes for its assimilation (glutamine synthethase, glutamate synthase) are repressed in bacteroids (Kahn et al., 1998; Kaminski et al., 1998).

In indeterminate nodules, $\mathrm{N}$ compounds which are exported to shoots are mainly glutamine and asparagine that contain $2 \mathrm{~N}$ atoms per 4-5 C atoms. However, in some legumes forming the determinate nodules (e. g., soybean or common bean) the assimilation is more specialized and the transport forms are represented by ureids (allantoine and allantoic acid) in which $\mathrm{N}$ : C ratio is close to $1: 1$. These compounds are synthesized in the plant cells that are not infected by rhizobia but are located in a close contact to the infected cells (Brewin, 1991).

One of the basic properties of nitrogenase is its high oxygen sensitivity: $\mathrm{N}_{2}$ can be fixed only under microaerobic $\left(<50 \mathrm{nM}\right.$ of $\left.\mathrm{O}_{2}\right)$ conditions required for nitrogenase stability. In the legume nodules, two barriers are created to protect $\mathrm{N}_{2}$-fixing bacteroids from $\mathrm{O}_{2}$ : structural and biochemical. The first one, called the diffusion barrier, consists of a tightly packed layer(s) of thick-walled cells in nodule parenchyma that isolates physically the infected central zone from $\mathrm{O}_{2}$ (Brewin, 1991). The second one consists of the leghemoglobin ( $\mathrm{Lb}$ ) which may constitute more than $50 \%$ of total proteins produced by the infected plant cells. Both parts of Lb molecule (polypeptide and heme) are encoded by the plant genes (O’Brian, 1996).

The principle strategy for formation of the integrated biochemical system in nodule is represented by the strictly coordinated expression of the partners' symbiotic genes. This expression was visualized as the synthesis of multiple "late nodulins" represented by $\mathrm{Lb}$ and by nodule-specific forms of $\mathrm{C}$ - and $\mathrm{N}$-metabolic enzymes synthesized after a decrease of $\mathrm{O}_{2}$ tension in nodules (Vance, Heichel, 1991; Hennecke, 2004). It looks probable that this expression is controlled by some signals coming from the bacteria cells. For example, in legume Sesbania the promoter of $L b 3$ gene contains two sites specific for the bacterial gene regulators. In Azorhizobium caulinodans (the Sesbania symbiont) the proteins were identified which bind these sequences and the bacterial mutations that knockout these proteins lead to a decrease in $\mathrm{Lb}$ synthesis and in $\mathrm{N}_{2}$-fixing activity (De Bruijn et al., 1994).

\subsection{Symbioses with $\mathbf{N}_{2}$-fixing cyanobacteria}

Some filamentous cyanobacteria (Nostoc, Anabaena) interact with plants forming the symbioses that differ in many respects from the legume nodules. These cyanobacteria can fix $\mathrm{N}_{2}$ in free-living state using the products of their own photosynthesis. Many mechanisms of the freeliving $\mathrm{N}_{2}$ fixation are involved in symbioses, but here they are controlled by hosts due to localization of cyanobacteria within special structures. In water fern Azolla, cyanobacteria are located within the leaf cavities, in gymnosperm Cycas - within the intercellular spaces of coralloid roots, in angiosperm Gunnera - within cells in the glands at the bases of leaf petiols (Bergman et al., 1994; Meeks, Elhai, 2002).

When transferred into $\mathrm{N}$-free medium, 5-10\% of cells distributed regularly along the filaments of free-living Nostoc and Anabaena are differentiated into the heterocysts that are (like the rhizobia bacteroids) devoid of reproductive ability. Heterocysts are enlarged and have thick walls blocking the oxygen entry. Due to arrest of photosynthesis, microaerobic conditions are reached inside heterocysts permitting the nitrogenase synthesis. In free-living cyanobacteria, glutamine synthetase (GS) is expressed along with nitrogenase and the primary product of $\mathrm{NH}_{4}^{+}$ assimilation (glutamine) is exported from heterocysts to the vegetative (photosynthetic) cells. The major source of ATP for nitrogenase reaction is photosystem I that, in contrast to photosystem II and Calvin cycle, retains its activity in heterocysts.

Development of cyanobacteria-plant symbioses is usually started with preinfection contacts, and the massive formation of motile hormogonia is induced in cyanobacteria that colonize the plant interiors. Within Gunnera glands, cyanobacteria propagate actively and infect the plant cells. After entering their cytoplasm, cyanobacteria are encapsulated into the symbiosome membranes and up to $80 \%$ of cells are converted into $\mathrm{N}_{2}$-fixing heterocycts (Bergman et al., 1994). They differ from free-living heterocysts since in symbiosis with Gunnera, the GS activity is lost by Nostoc and $\mathrm{NH}_{4}{ }^{+}$is exported into the plant cells. The principal sources of $\mathrm{C}$ skeletons and energy for heterocyst are the sugars provided by plant host since the own photosynthesis in symbiotic cyanobacteria is almost absent (Meeks, Elhai, 2002).

A unique feature of $\mathrm{N}_{2}$-fixation in cyanobacteria is constituted by the programmed rearrangements of nif genes. In the vegetative Anabaena cells the nitrogense structural gene nifD is split by a $11 \mathrm{~kb}$ DNA segment, and integrity of this gene is restored during the heterocyst differentiation. This restoration is controlled by the site-specific endonuclease $x i s A$ gene located within the $11 \mathrm{~kb}$ segment which may be found as a plasmid in the $\mathrm{N}_{2}$-fixing heterocysts (Golden et al., 1991).

When we compare legume-rhizobia and plant-cyanobacteria symbioses a range of contrasts may be revealed with respect to structures and biochemical activities of partners' cells. However, the important general principles of the symbioses operation are evident too (Table 3 ). In both of them the microbial $\mathrm{N}_{2}$ fixation is combined with the plant photosynthesis resulting in integrated partners' $\mathrm{C} / \mathrm{N}$ biochemical pathways. During symbioses, the energy supply of microbial $\mathrm{N}_{2}$-fixing machinery as well as assimilation of $\mathrm{NH}_{4}{ }^{+}$are implemented mainly by hosts. Deep and mainly irreversible cellular differentiation before the onset of $\mathrm{N}_{2}$ fixation occurs in rhizobia (bacteroids) and in cyanobacteria (heterocysts). 
Table 3

Comparison of two types of $\mathbf{N}_{2}$-fixing plant-microbe symbiosis

\begin{tabular}{|c|c|c|}
\hline \multirow{2}{*}{ Properties } & \multicolumn{2}{|c|}{ Symbioses between } \\
\hline & rhizobia and legumes & cyanobacteria and plants \\
\hline Specificity of interaction & $\begin{array}{l}\text { Narrow: great majority of rhizobia inocu- } \\
\text { late only the restricted groups of legumes }\end{array}$ & $\begin{array}{l}\text { Broad: Nostoc inoculates different types } \\
\text { of plants }\end{array}$ \\
\hline Impacts of plant signals on microbes & $\begin{array}{l}\text { Activation of nod-genes (by plant flavo- } \\
\text { noids) }\end{array}$ & Massive formation of motile hormogonia \\
\hline $\begin{array}{l}\text { Plant structures which contain micro- } \\
\text { symbionts }\end{array}$ & $\begin{array}{l}\text { Develop de novo in the result of symbiotic } \\
\text { interaction (root or stem nodules) }\end{array}$ & $\begin{array}{l}\text { Exist before symbiotic interaction al- } \\
\text { though are fully developed after coloniza- } \\
\text { tion by bacteria (glands, tissue cavities, } \\
\text { coralloid roots) }\end{array}$ \\
\hline $\begin{array}{l}\text { Differentiation of nitrogen-fixing bacterial } \\
\text { cells }\end{array}$ & Only in plants (bacteroids) & $\begin{array}{l}\text { In plants and in free-living state (hetero- } \\
\text { cysts) }\end{array}$ \\
\hline $\begin{array}{l}\text { Penetration of micro-symbionts into plant } \\
\text { cells }\end{array}$ & In the majority of legumes & Only in Gunnera glands \\
\hline $\begin{array}{l}\text { Rearrangements of } \text { nif-genes prior to } \mathrm{N}_{2} \\
\text { fixation onset }\end{array}$ & Not shown & Typical \\
\hline Source of ATP for nitrogenase reaction & Respiratory chain & Photosystem I \\
\hline Protection of nitrogenase from oxygen & $\begin{array}{l}\text { Mainly by plants (leghemoglobin and dif- } \\
\text { fusion barrier in nodules) }\end{array}$ & $\begin{array}{l}\text { Mainly by bacteria (cell wall of hetero- } \\
\text { cysts) }\end{array}$ \\
\hline
\end{tabular}

\section{ARBUSCULAR MYCORRHIZA}

Mycorrhizae represent the universal type of plant-microbe symbiosis formed by the root-colonizing fungi wherein a part of mycobiont is inside the root while the other part is outside of it (Smith, Read, 1997). Separation of the mycobiont into intra- and extra-radical portions reflects the basic function of mycorrhizae as of intermediates between plant and soil. This function is of global ecological importance since only few plants (mainly short-living herbs and aquatic forms) cover their demands in nutrients and water without an aid of mycobionts. Based on their anatomy, mycorrhizae are classified into endomycorrhizae (the major part of mycobiont is located inside the root; the fungal hyphae penetrate the plant cells and develop the specialized sub-cellular compartments) and ectomycorrhizae (the roots contain a minor part of mycobiont the distribution of which is restricted to intercellular spaces).

The first type is represented by the well studied and ecologically most important arbuscular mycorrhiza (AM) formed by the great majority ( $>80 \%$ ) of land plants. The genetic organization of the AM-fungi reclassified recently as Glomeromycota (Schußler, 2002) looks intriguing since they combine the absence of sexual reproduction with extremely high genetic diversity (Dodd et al., 1996) and inability to propagate independently of plants with the huge $(100-1000 \mathrm{Mb}$ ) genome size (Tunlid, Talbot, 2002). The heterocaryotic mycelia and spores of AM fungi harbor thousands of genetically variable haploid nuclei (Lloyd-MacGilp et al., 1996). These features complicate greatly the genetic analysis of AM fungi and nearly all information on the control of this symbiosis is obtained by means of plant genetics.

\subsection{Development}

AM development involves pre-infection, formation of intra-radical (intercellular) mycelium, development of subcellular symbiotic structures and of sporulating extraradical mycelium (Hahn, Mendgen, 2001). This development starts with the germination of the fungal spores and the brunching growth of germ tubes elicited by the plant exudates. Recently the plant signals ("branching factors") inducing these processes were elucidated in the model legume Lotus japonicus as strigolactones which are close to the inducers for germination of seeds in parasitic angiosperms Striga and Orobanche (Akiyama et al., 2005). The pre-infection fungal growth induced by these signals is reversible: if do not attach a root within $5-7$ days, the germ tubes abort and the nutrients are returned into spore (Bago et al., 1999). The huge size (up to $0.5 \mathrm{~mm}$ ) and high metabolic potential of spores permits AM fungi to repeat several times their attempts to reach the root.

After the root is found, the germ tubes form the attachment structures, appressoria from which the infective hyphae start and colonize outer and inner cortex but never cross the pericycle. After establishing a network of intercellular hyphae, fungus develops arbuscules which penetrate the plant cells and fill a sufficient parts of their volumes.

The plant cells containing arbuscules undergo a pronounced differentiation to ensure hosting of the mycobiont. The vacuole is reduced or degraded, the amount of $\alpha$-tu- 
bulin is increased, the nucleus is deformed (sometimes it becomes surrounded by the branches of arbuscule) and chromatin is decondensed due to its high transcriptional activity. The amount of endoplasmic reticulum and Golgi vesicles is increased greatly ensuring the biogenesis of periarbuscular membranes. The latter are separated from the fungus surface by an apoplast that contains polysaccharides and enzymes of the mixed (plant and fungal) origins (Harrison, 1998). The arbuscules are short-living structures: every $4-7$ days they are digested by plant cells and the novel arbuscules may be developed (Harrison, 1999).

The final developmental stage in AM is represented by formation of the extra-radical hyphae that are of crucial importance for both partners. For the host, nutritional functions of these hyphae (absorption of soil nutrients) are important, while for the mycobiont the reproductive function (sporulation) is indispensable. The extended system of extra-radical hyphae (70-80 m per $1 \mathrm{~m}$ of root length) permits the mycobiont to explore carefully the soil around roots scavenging the nutrients. An important property of the extra-radical hyphae is represented by their ability to penetrate the roots of neighboring plants, enabling the allocation of nutrients and energy across the plant community resulting in its stability and diversity (Smith, Read, 1997).

Development of AM fungi within the root is controlled strictly by host; the regulatory processes induced within the root cortex during AM development include: modification of the cell walls, synthesis of flavonoid phytoalexins, accumulation of callose and pathogen-regulated (PR) proteins, including peroxidases and lytic enzymes (Gianinazzi-Pearson et al., 1996). However, upon Glomus inoculation the intensity of these defence-like reactions is low, they are less prolonged and more differentiated in time and space since the plant defence reactions are repressed by some fungal signals (Kapulnik et al., 1996; Provorov et al., 2002).

The analyses of plant control over AM development have been started using the legume mutants defective in early nodule development since these mutants are often arrested in AM formation (Duc et al., 1989; Borisov et al., 1992). The resulted phenotypes were classified into two groups: $\mathrm{Myc}^{-1}$ and $\mathrm{Myc}^{-2}$. The first one is composed of mutants in which $\mathrm{AM}$ development is blocked just after formation of appressoria and the infective hyphae are aborted when penetrating the epidermis. Phenotype $\mathrm{Myc}^{-1}$ was revealed in legume mutants defective in the root hair curling which occurs after rhizobia inoculation. The $\mathrm{Myc}^{-2}$ mutants form apressoria and intercellular mycelium after Glomus inoculation, however arbuscules are not developed. $\mathrm{Myc}^{-2}$ phenotype was identified in the legume mutants arrested at the later stages of nodule development (e. g., rhizobia endocytosis into plant cells) (Buttery, Park, 1993).

The analysis of the legume mutants allowed researches to identify a range of genes involved in control of both mutualistic symbioses (Hahn, Mendgen, 2001). However, this approach does not cover the whole AM developmental program since the defects in pre-infection processes were not identified in the nodulation-arrested legume mutants. The mutants defective in eliciting spore germination and appressoria formation were obtained via a direct selection of $\mathrm{AM}^{-}$phenotypes in legumes (Medicago truncatula) and non-legumes (tomato, maize) (Klingler et al., 1995; Cordier et al., 1998; Barker et al., 1988; David-Schwartz et al., 2001, 2003; Marsh et al., 2006).

From the practical viewpoint, the plant genotypes with an increased AM development look attractive. Some of them were selected among the legume $\mathrm{Nod}^{++}$mutants impaired in AON suggesting the common mechanisms for systemic regulation of nodulation and mycorrhization (Krussel et al., 2002). An enhanced AM development was detected in Medicago truncatula lines with an increased activity of chitinase class III (MtChit-3) gene (Hause et al., 2002) or of ENOD40 gene involved in the hormonal control of nodulation (Staehelin et al., 2001). Expression of these genes in the cells infected by arbuscules suggest their roles in development of these endosymbiotic structures.

Numerous similarities between AM and nodulation were revealed at the molecular level. Mycorrhization stimulates the de novo synthesis of proteins (mycorrhizins) which are absent in non-inoculated roots. They comprise $4-5 \%$ of the total root proteins, and in the legumes some of them are common to early nodulins (ENOD2, ENOD11, ENOD12, ENOD40) and to Lb which is weakly synthesised in the plant cells containing arbuscules (Gianinazzi-Pearson, Gianinazzi, 1995). In M. truncatula roots, 300-400 genes are induced during $\mathrm{AM}$, and about 100 of then are common to the nodulation program (Küster et al., 2007). A range of common genes are involved in signalling cascades regulating root nodulation and development of AM in legumes (Hahn, Mendgen, 2001). These data suggest that in the course of legume evolution, some genes were recruited from the ancient AM program into the more young nodulation program (Gianinazzi-Pearson, 1996).

\subsection{Metabolism}

The adaptive gains obtained by plants and fungi from AM formation are based on their active exchange by nutrients. Due to the ability for intensive osmotrophic nutrition, mycobiont collects broad spectrum of macroand micro-elements required by host, however, the most pronounced effects pertain the phosphorous nutrition (Smith, Read, 1997). This function is very important for the plant survival because the major part of $\mathrm{P}$ in soils is represented by unsolvable compounds that can not be assimilated by roots directly (Vance, 2001). In Pisum sativum genotypes the comparative $(\%)$ increases in the $\mathrm{P}$ content obtained by plants due to inoculation with Glomus are sufficiently more than the increases in $\mathrm{N}$ and $\mathrm{K}$ contents or in plant biomass (Martensson, Rydberg, 1994; Jakobi et al., 2000) suggesting the specific mechanisms for $\mathrm{P}$ assimilation. 
The biochemical data support this suggestion since the uptake of $\mathrm{P}$ from soils (which occurs in soluble forms, mainly as $\mathrm{H}_{2} \mathrm{PO}_{4}{ }^{-}$addressed as $\mathrm{P}_{\mathrm{i}}$ ) involves several transport systems some of which have an extremely high affinity for $\mathrm{P}_{\mathrm{i}}$ (Ezawa et al., 2002). After transporting into hyphae, the major part of $\mathrm{P}_{\mathrm{i}}$ is included into polyphosphates - linear chains of $\mathrm{P}_{\mathrm{i}}$ (polymerization is catalyzed by the polyphosphate kinase). The granules rich in polyphosphates and in the P-containing esters move along the hyphae being packed into cylindrical vacuoles the transport of which is facilitated by tubulin fibrils (Ashford, 2002). After reaching the arbuscules, P-compounds are destroyed by phosphatases and the released $\mathrm{P}_{\mathrm{i}}$ cross the partners' interface. The crucial role of arbuscules in $\mathrm{P}_{\mathrm{i}}$ export was proved by the dependence of their development on the soil P status: arbuscules are formed actively under the limited or moderate $\mathrm{P}_{\mathrm{i}}$ supply, while the absence or excess of $\mathrm{P}_{\mathrm{i}}$ block their formation.

Inoculation by AM fungi can improve also the $\mathrm{N}$ content in plants. An interesting hypothesis concerning this improvement may be deduced from the data demonstrating that some AM fungi harbor obligatory endosymbiotic bacteria close to Burkholderia. In these bacteria, nif genes encoding for nitrogenase were found and their in planta expression was demonstrated that may result in $\mathrm{N}_{2}$ fixation (Minerdi et al., 2002). Its real impact on the plant growth needs precise evaluation, however, high adaptive potential of this tripartite symbiosis is evident since the active $\mathrm{P}$ accumulation may lead to an imbalanced plant metabolism if not accompanied by an improved $\mathrm{N}$ supply.

In order to support the mycobiont activity, reverse flow of $\mathrm{C}$ compounds from host occurs via arbuscules and interfaces between plant cells and intercellular hyphae. Fungi receive these products as the hexoses which resulted from destruction of sucrose by acid invertases located on the plant cell surfaces (Bago et al., 2000). The major part of carbon obtained by fungus is included into the storage and transport forms: lipids, glycogen and trehalose. They are packed into the granules suitable to transport from intrato extra-radical mycelium. The major part of plant-derived $\mathrm{C}$-compounds is used to provide energy for developing the external mycelium as well as for its osmotrophic and spore forming activities.

\section{DEFENSIVE SYMBIOSES}

One of the basic strategies in plant-microbe interactions is to restrict the activities of hosts' natural enemies: pathogenic microbes and phytophagans. The defensive symbioses differ from the nutritional ones $\left(\mathrm{N}_{2}\right.$-fixing symbioses and mycorrhizae): protective functions do not require the bilateral metabolic exchange since the symbiotically essential microbial compounds are produced in tiny dosages and are used not to feed the host but to suppress the antagonistic organisms. A potential to be used in ecologically friendly agriculture for biocontrol of various pests attracts a great attention to the defensive symbioses. Since the defense from fungal pathogens by plant growth promoting bacteria (PGPR) and by endophytic bacteria will be covered in this volume by the other authors (Lugtenberg and Kamilova, 2008; Berg et al., 2008), we shall concentrate here on the defense of plants from phytophagans.

Plants support in their tissues a variety of endophytic or epiphytic microbes which synthesize the protective substances against invertebrate or vertebrate phytophagans. The best studied are ergot fungi (Clavicipitaceae, Ascomycota): Claviceps, Neotyphodium (formerly Acremonium) and Epichloë. They implement the complicated living cycles including asexual and sexual reproduction and a very interesting phenomenon of obligatory involvement of insects into the conidia dispersal (Schardl et al., 1997).

For Neotyphodium and some Epichloë genotypes, vertical transmission through the host generations was demonstrated which can ensure the maintenance of endophytes in the plant populations. Infections by these fungi may result in diverse impacts on the plant fitness including not only beneficial but some deleterious effects too. Interactions with Neotyphodium are predominantly mutualistic: endophytes synthesize alkaloids lolins and peramins which make the plant toxic to some insect pests (aphids, weevils, larvae of beetles and butterflies). The gene cluster controlling the synthesis of insecticidal nor-loline was recently mapped and sequenced in N. uncinatum (Spiering et al., 2005). In addition, Neotyphodium induce vegetative plant development and improve resistance to some abiotic stresses, for example to drought (Schardl, 2001; Schardl et al., 2004). However, the related Epichloë spp. often combine the protective and pathogenic effects (e. g., chock disease resulted in suppression of developing the reproductive tillages in cereals).

Unfortunately, many Neotyphodium strains produce alkaloids loliterm B and ergovaline deleterious for cattle; the latter compound is produced also by the ergot fungus Claviceps (Tudzynski, Scheffer, 2004). However, Neotyphodium strains devoid of vertebrate-toxic compounds may be constructed and introduced into the plants since the genes encoding for toxicity are not required for the host colonization (Spiering et al., 2005). The "unarmed" strains may be used to exclude the inoculation of commercial cereal varieties by the toxin-producing endophytes.

An interesting group of plant protectors is represented by Clavicipitaceaen genus Cordyceps, a symptom-less or moderately pathogenic epiphytes which cause the lethal infections in phytophagous insects. These infections are initiated by feeding the insects on epiphyte-harboring plants and are resulted in development of mycelia and fruiting bodies just in the killed pests (White et al., 2002).

As one can conclude from the data on Clavicipitaceae fungi, the analyses of defensive symbioses are required not only to organize the biocontrol of pests but also to avoid the 
plant toxicity for domestic animals and for humans. The importance of the latter approach is valid for the plant infections by the Gram-positive coryneform bacterium Clavibacter toxicus which was found in the broad spectrum of crops including grain, fodder and vegetable ones (Dorofeeva et al., 2002). In the natural communities, this endophyte if disseminated mainly via nematodes Anguina spp. Presence of $C$. toxicus in the shoots of fodder crops (ryegrass, fescues) often leads to the "staggers" in cattle, the annual lost from which in New Zealand, Australia and USA is estimated in hundreds of million dollars. A potential of A. tritici to transmit $C$. toxicus from the fodder cereals to wheat may be dangerous for humans (Riley, Reardon, 1995). The bacterial production of "corynetoxins" is dependent on some bacteriophages which may encode for essential stages of the toxin biosynthesis or for its regulation (Metzler et al., 1997).

\section{CONSTRUCTION OF SUSTAINABLE AGRO- SYSTEMS}

Intensive genetic, molecular and ecological research on plant-microbe symbioses demonstrate that the plant organism should be investigated and manipulated not as a chemical machinery which synthesize the organic compounds using the solar energy but as an organizer of the symbiotic communities where many vital (trophic, defensive, some regulatory) functions are delegated from hosts to their microsymbionts (Tikhonovich, Provorov, 2007). This approach opens broad prospects for the symbioses improvement and application in the sustainable agricultural systems in which the high crop productivity may be reached under a minimized application of mineral fertilizers and plant protecting dyes.

Unfortunately, beneficial plant-microbe systems was imbalanced greatly in the cultured flora. During the domestication and breeding of plants, the humans learned to implement many of their vital functions using agrochemicals (mineral fertilizers, pesticides) and agrotechnical procedures. The broad application of these techniques underlies the "intensive agriculture" strategy, however, the ecological price of its development expressed as a global pollution of environment appeared to be unexpectedly high (Vance, 2001). A sufficient part of it is due to the chemical transformations of $\mathrm{N}$ and $\mathrm{P}$ fertilizers the products of which accumulate in soil and water leading to the adverse ecological changes. The plant-protective dyes and the products of their degradation may be transformed into toxic substances that reach humans through the food chains. The real alternatives to these agrochemicals are represented by microbial inoculants without which no ecologically friendly agriculture is possible (Sessitsch et al., 2002). Of course, these inoculants will not substitute totally the fertilizers or pesticides but may decrease manyfold the levels of their application.
Broad analysis of variation in the agronomically important symbiotic traits in plant-microbial systems suggests some general approaches which should underlie their genetic improvement. The first one may be deduced from the data demonstrating that many of the broadly used legume crops are defective in the responsiveness to rhizobial inoculation (Provorov, Tikhonovich, 2003). For example, "old" crops having a prolonged history of cultivation and breeding (alfalfa Medicago sativa, pea Pisum sativum, soybean Glycine max, polebean Phaseolus vulgaris) grow better under the combined $\mathrm{N}$ supply than under inoculation with rhizobia strains. However, some "young” crops (Kura clover Trifolium ambiguum, hairy vetch Vicia villosa, goats' rue Galega orientalis) usually prefer to use symbiotically fixed $\mathrm{N}_{2}$. Moreover, in pea and alfalfa, the wild-growing genotypes and local varieties exceed the agronomically advanced cultivars in the $\mathrm{N}_{2}$-fixing activity. Similar difference between wild-growing and cultivated plant genotypes were reported for AM symbiosis in pea (Jakobi et al., 2000) and for PGPR associations in wheat (Kravchenko, Leonova, 1993).

These data suggest that during domestication and breeding, plants lost their symbiotic potential, and the special efforts from breeders and gene engineers are required to improve it using the genetic resources of wild-growing germplasm. A validity of this approach was demonstrated in polebean: introduction of genes for high $\mathrm{N}_{2}$-fixing activity from wild-growing (climbing) lines into agronomically advanced (bush) cultivars created the commercially attractive genotypes which combine the "cultured" phenotype with high $\mathrm{N}_{2}$-fixing activity (Bliss, 1993).

An important prerequisite for improving the efficiency of symbiotic systems is the coordination of genetic modifications in plants and their microsymbionts. Two-factor analysis of variance of the data on interactions between different plant cultivars and rhizobia strains suggests that the symbiotic efficiency is controlled by genotypes of both partners. However, the highly effective symbioses are formed when the non-additive genetypic effects resulted from the specific cultivar-strain interactions are most pronounced (Rengel, 2002; Provorov, Tikhonovich, 2003). Therefore, coordinated improvement of partners should be aimed at creating the optimal (complementary) combinations of plant and microbial genotypes. The potential output of this work is very high: in major legume crops the amount of fixed nitrogen may be increased by 3-4 times by means of different genetic manipulations (Provorov, Tikhonovich, 2003). The specific approaches and techniques to be used in this work are broadly reviewed in the literature (Barnes et al., 1984; Rengel, 2002; Sessitch et al., 2002; Provorov, Tikhonovich, 2003)

\section{CONCLUSION}

Molecular research demonstrated that different types of plant-microbe symbiosis (nutritional and defensive) are 
based on the deep functional integration of the partners' genes which is mediated by the signaling interactions. The symbiosis-specific phenotypes acquired by partners are expressed as the development of novel tissue/cellular structures, metabolic functions and adaptive capacities. It is important to note that in order to cooperate with beneficial microbes the plants use a range of universal factors permitting them to avoid a hyper-complications in their genomes which would be required to harbor genes for multiple adaptive functions. Instead, the plants retain a restricted number of genes for hosting various microorganisms, evolutionary reorganizing these genes to adapt the new symbiotic partners and to meet the novel environmental challenges.

From the study of plant-microbe interactions, a novel view of sustainable crop production is suggested as of a methodology of substituting the agrochemicals (mineral fertilizers, plant protective dyes) by the microbial metabolites. An improvement of plant-microbe symbioses should involve the reorganizations of the integrated genetic systems based on a coordinated modifications in the plant and microbial genotypes. In future, the sustainable agriculture should switch from growing the plants to the cultivation of genetically constructed plant-microbial communities which can reach a high productivity under the restricted energy and chemical investments and with the minimal pressures on the environment. However, at present we are still at the beginning of this construction and much more co-operation of experts on the plant and microbial genetics, molecular biology and ecology is required to reach a pronounced success in purchasing the sustainable microbial-based agrotechnologies.

\section{ACKNOWLEDGEMENTS}

The research presented in this paper is supported by grants from Russian Foundation of Basic Research (04-0448457, 06-04-48800, 06-04-89000NWO); NWO Centre of Excellence: 047.018.001.

\section{Literature}

1. Akiyama K., Matsuzaki K., Hayashi H., 2005. Plant sesquiterpenes induce hyphal branching in arbuscular mycorrhizal fungi // Nature. Vol. 435. P. 824-827.

2. Allen O. N., Allen E. K., 1981. The Leguminosae. A source book of characteristics, uses and nodulation. Wisconsin: Univ. Wisconsin Press, 800 p.

3. Ashford A., 2002. Tubular vacuoles in arbuscular mycorrhizas // New Phytologist. Vol. 154. P. 545-547.

4. Bago B., Pfeffer P. E., Douds D. D., Brouillette J. et al., 1999. Carbon metabolism in spores of the arbuscular mycorrhizal fungus Glomus intraradices as revealed by nuclear magnetic resonance spectroscopy // Plant Physiol. Vol. 121. P. 263-271.
5. Bago B., Pfeffer P. E., Shacher-Hill Y., 2000. Carbon metabolism and transport in arbusclar mycorrhizas // Plant Physiology. Vol. 124. P. 949-957.

6. Balachandar D., Raja P., Kumar K., Sundaram S. P., 2007. Non-rhizobial nodulation in legumes // Biotechnol. Molec. Biol. Rev. Vol. 2. P. 49-57.

7. Barker S. J., Stummer B., Gao L., Dispain I. et al., 1988. A mutant in Lycopersicon esculentum Mill. with highly reduced VA mycorrhizal colonization: isolation and preliminary characterization // The Plant J. V. 15. P. $791-797$.

8. Barnes D. K., Heichel G. H., Vance C. P., Ellis W. R., 1984. A multiple-trait breeding program for improving the symbiosis for $\mathrm{N}_{2}$ fixation between Medicago sativa L. and Rhizobium meliloti // Plant and Soil. Vol. 82. P. 303-312.

9. Berg G., Müller H., Zachow C. et al., 2008. Endophytes: structural and functional diversity and biotechnological applications in control of plant pathogens // This Issue.

10. Bergman B., Johansson C., Matveyev A., Rasmussen U., 1994. Communication and early events during establishment of a cyanobacterial-plant symbiosis // Proc. 1-st European Nitrogen Fixation Conference / Eds. Kiss G., Endre G. Szeged: Officina Press. P. 190-194.

11. Beveridge C. A., Mathesius U., Rose R. J., Gresshoff P., 2007. Common regulatory themes in meristem development and whole-plant homeostasis // Curr. Opin. Plant Biol. Vol. 10. P. 44-51.

12. Bliss F., 1993. Breeding common bean for improved biological nitrogen fixation // Plant and Soil. Vol. 152. P. $71-79$.

13. Borisov A. Y., Danilova T. N., Koroleva T. A., Naumkina T. S. et al., 2004. Pea (Pisum sativum L.) regulatory genes controlling development of nitrogen-fixing nodule and arbuscular mycorrhiza: fundamentals and application // Biologia. Vol. 59/Suppl 13. P. 137-144.

14. Borisov A. Y., Morzhina E. V., Kulikova O. A., Tchetkova S. A. et al., 1992. New symbiotic mutants of pea (Pisum sativum L.) affecting either nodule initiation or symbiosome development // Symbiosis. Vol. 14. P. $297-313$.

15. Borisov A. Y., Rozov S. M., Tsyganov V. E., Morzhina E. $V$. et al., 1997. Sequential functioning of Sym-13 and Sym-31, two genes affecting symbiosome development in root nodules of pea (Pisum sativum L.) // Molec. Gen. Genet. Vol. 254. P. 592-598.

16. Breedveld M. J., Miller K. J., 1994. Cyclic $\beta$-glucans of members of the family Rhizobiaceae // Microbiol. Rev. Vol. 58. P. 145- 161.

17. Brewin N. J., 1991. Development of the legume root nodule // Annu. Rev. Cell Biol. Vol. 7. P. 191-226.

18. Brewin N. J., 2004. Novel symbiotic organelles in the Rhizobium-legume interaction // Biology of Plant-Mi- 
crobe Interactions / Eds. I.A. Tikhonovich et al., St.Petersburg: IS-MPMI. P. 476-482.

19. Brom S., Martinez E., Davila G., Palacios R. et al. 1988. Narrow and broad-host range symbiotic plasmids of Rhizobium spp. strains that nodulate Phaseolus vulgaris // Appl. Environ. Microbiol. Vol. 54. N 5. P. 1280-1283.

20. Broughton W. J., Perret X., 1999. Genealogy of legumeRhizobium symbiosis // Curr. Opinion in Plant Biology. Vol. 2. P. 305-311.

21. Buttery B. R., Park S. J., 1993. Characterization of some non-fixing mutants of common bean (Phaseolus vulgaris L.) // Canad. J. Plant Sci. Vol. 73. P. 977-983.

22. Conclin M. E., 1936. Studies of the root nodule organisms of certain wild legumes // Soil Sci. Vol. 41. N 3. P. 167- 185 .

23. Cordier C., Pozo M. J., Barea J. M., 1998. Cell defense responses associated with localized and systemic resistance to Phytophthora parasitica induced in tomato by arbuscular mycorrhizal fungus // Molec. Plant-Microbe Interact. Vol. 11. P. 1017-1028.

24. David-Schwartz R., Badani H., Smadar W., Levy A. A. et al., 2001. Identification of a novel genetically controlled step in mycorrhizal colonization: plant resistance to infection by fungal spores but not extra-radical hyphae // The Plant J. Vol. 27. P. 561-569.

25. David-Schwartz R., GadkarV., Smadar W., Bendov R., et al., 2003. Isolation of a premycorrhizal infection (pmi2) mutant in tomato, resistant to arbuscular mycorrhizal fungal colonization // Molec. Plant-Microbe Interact. Vol. 16. P. 382-388.

26. De Bruijn F., Chen R., Fujimoto S. Y., Pinaev A., et al., 1994. Regulation of nodulin gene expression // Plant and Soil. Vol. 161. P. 59-68.

27. Dodd J. C., Rosendahl S., Giovannetti M., Broome A., et al., 1996. Inter- and intraspecific variation within the morphologically similar arbuscular mycorrhizal fungi Glomus mosseae and Glomus coronatum // New Phytologist. Vol. 133. P. 113-122.

28. Dolgikh E. A., Leppyanen I. V., Osipova M. A., Tikhonovich I. A., 2008. Role of signal exchange in control of Rhizobium - legumes symbiosis specificity // This Issue.

29. Dorofeeva L. V., Evtushenko L. I., Krausova V. I., Karpov A. V. et al., 2002. Rathayibacter caricis sp. nov. and Rathayibacter festucae sp. nov., isolated from the phyllosphere of Carex sp. and the leaf gall induced by the nematode Anguina graminis on Festuca rubra L., respectively // Intern. J. System. Evol. Microbiol. Vol. 52. P. 1917-1923.

30. Duc G., Trouvelot A., Gianinazzi-Pearson V., Gianinazzi S., 1989. First report on non-mycorrhizal plant mutants $\left(\mathrm{Myc}^{-}\right)$obtained in pea (Pisum sativum L.) and fababean (Vicia faba L.) // Plant Sci. Vol. 60. P. 215-222.
31. Ezawa S., Smith S. E., Smith F. A., 2002. P metabolism and transport in AM fungi // Plant and Soil. V. 244. P. $221-230$.

32. Fisher H. M., 1994. Genetic regulation of nitrogen fixation in rhizobia // Micrbiol. Rev. V. 58. P. 352-386.

33. Franssen H. J., Nap J. P., Bisseling T., 1992. Nodulins in root nodule development // Biological Nitrogen Fixation / Eds. G. Stacey et al., New York, London: Chapman and Hall. P. 598-624.

34. Gamas P., de Billy F., Truchet G., 1998. Symbiosisspecific expression of two Medicago truncatula nodulin genes, MtM1 and MtN13 encoding products homologous to plant defense proteins // Molec. Plant-Microbe Interact. Vol. 11. P. 393-403.

35. Gianinazzi-Pearson V., 1996. Plant cell responses to arbuscular mycorrhizal fungi: getting to the roots of the symbiosis // The Plant Cell. Vol. 8. P. 1871-1883.

36. Gianinazzi-Pearson V., Dumas-Gaudot E., Gollotte A., Tahiri-Alaoni A. et al., 1996. Cellular and molecular defense-related root responses to invasion by arbuscular mycorrhizal fungi // New Phytologist. Vol. 133. P. 45-57.

37. Gianinazzi-Pearson V., Gianinazzi S., 1995. Proteins and protein activities in endomycorrhizal symbioses // Mycorrhiza / Eds. A. Varma, B. Hock, Berlin, Heidelberg: Springer-Verlag. P. 251-266.

38. Golden J. W., Whoff L. L., Wierts D. R., 1991. Independent regulation of nifHDK operon transcription and DNA rearrangements during heterocyst differentiation in the cyanobacterium Anabaena sp. strain PCC7120 // J. Bacteriol. Vol. 173. P. 7098-7105.

39. Hahn M., Mendgen K., 2001. Signal and nutrient exchange at biotrophic plant-fungus interfaces // Curr. Opin. Plant Biol. Vol. 4. P. 322-327.

40. Harrison M., 1998. Development of the arbuscular mycorrhizal symbiosis // Curr. Opin. Plant Biol. Vol. 1. P. 360-365.

41. Harrison M., 1999. Molecular and cellular aspects of the arbuscular mycorrhizal symbiosis // Annu. Rev. Plant Physiol. Plant Molec. Biol. Vol. 50. P. 361-389.

42. Hause B., Maier W., Miersch O., Kramell R. et al., 2002. Induction of jasmonate biosynthesis in arbuscular mycorrhizal barley roots // Plant Physiol. Vol. 130. P. 1213-1220.

43. Hennecke H., 2004. Regulation of rhizobial life in symbiosis // Biology of Plant-Microbe Interactions / Eds. I. A. Tikhonovich et al., St.-Petersburg: IS-MPMI. P. 411-415.

44. Jakobi L. M., Kukalev A. S., Ushakov K. V., Tsyganov $V$. E. et al., 2000. Polymorphism of garden pea in the efficiency of symbiosis with endomycorrhizal fungus Glomus sp. under the conditions of inoculation with rhizobia // Agricultural Biology (in Russian). Vol. 3. P. 94-102.

45. Jensen H. L., 1967. Mutual host plant relationships in two groups of legume root nodule bacteria (Rhizo- 
bium spp.) // Archiv für Mikrobiologie. Vol. 59. N 1-3. P. 174-179.

46. Jording D., Uhde C., Schmidt R., Puhler A., 1994. The C4-dicarboxylate transport system of Rhizobium meliloti and its role in nitrogen fixation during symbiosis with alfalfa (Medicago sativa) // Experientia. Vol. 5. P. 874-883.

47. Kahn M. L., McDermott T. R., Udvardi M. K., 1998. Carbon and nitrogen metabolism in rhizobia // The Rhizobiaceae. Molecular Biology of Model Plant-Associated Bacteria / Eds. H. Spaink et al., Dordrecht, Boston, London: Kluwer Acad. Publ. P. 461-485.

48. Kaminski P., Batut J., Boistard P., 1998. A survey of symbiotic nitrogen fixation by rhizobia // The Rhizobiaceae. Molecular Biology of Model Plant-Associated Bacteria / Eds. H. Spaink et al., Dordrecht, Boston, London: Kluwer Acad. Publ. P. 431-460.

49. Kannenberg E. L., Reuhs B. L., Forsberg L. S., Carlson R. W., 1998. Lipopolysaccharides and K-antigens: their structures, biosynthesis and functions // The Rhizobiaceae. Molecular Biology of Model Plant-Associated Bacteria / Eds. H. Spaink et al., Dordrecht, Boston, London: Kluwer Acad. Publ. P. 119-154.

50. Kapulnik Y., Volpin H., Itzhaki H., Ganon D. et al., 1996. Suppression of defence responses in mycorrhizal alfalfa and tobacco roots // New Phytologist. Vol. 133. P. $59-64$.

51. Kinkema M., Scott P. L., Gresshoff P., 2006. Legume nodulation: successful symbiosis through short- and long-distance signaling // Functional Plant Biology. Vol. 33. P. 707-721

52. Klingler A., Bothe G., Wray V., 1995. Identification of a yellow pigment formed in maize roots upon mycorrhizal colonization // Phytochemistry. Vol. 38. P. 53-55.

53. Kravchenko L. V., Leonova E. V., 1993. Use of tryptophan of root exo-metabolites during the biosynthesis of indolil-3-acetic acid by associative bacteria // Mikrobiologia (in Russian). Vol. 62. P. 453-459.

54. Krussel L., Madsen L. H., Sato S., 2002. Shoot control of root development and nodulation is mediated by a receptor-like kinase // Nature. Vol. 420. P. 422.

55. Küster H., Vieweg M. F., Manthey K., Baier M. C. et al., 2007. Identification and expression regulation of symbiotically activated legume genes // Phytochemistry. Vol. 68. P. 8-18.

56. Lloyd-MacGilp S. A., Chambers S. M., Dodd J. C., Fit$\operatorname{ter} A$. H., et al., 1996. Diversity of the ribosomal internal transcribed spaces within and among isolates of Glomus mosseae and related mycorrhizal fungi // New Phytologist. Vol. 133. P. 103-112.

57. Lugtenberg B., Kamilova F., 2008. Beneficial rhizosphere pseudomonads // This Issue.

58. Madsen E. B., Madsen L. H., Radutoiu S., Olbryt M., et al., 2003. A receptor kinase gene of the LysM type is involved in legume perception of rhizobial signals // Nature. Vol. 425. P. 637-640.
59. Marsh J., Schultze M., Oldroyd G., 2006. Isolation and analysis of Medicago truncatula mutants defective in the arbuscular mycorrhizal symbiosis // Abstr. 3-d Intern. Conf. "Legume Genomics and Genetics". Australia, Brisbane, p. 52.

60. Martensson A., Rydberg I., 1994. Variability among pea varieties or infection with arbuscular mycorrhizal fungi // Swedish J. Agric. Res. Vol. 24. P. 13-19.

61. Meeks J. C., Elhai J., 2002. Regulation of cellular differentiation in filamentous cyanobacteria in free-living and plant-associated symbiotic growth states // Microbiol. Molec. Biol. Rev. Vol. 66. P. 94-121.

62. Metzler M. C., Laine K. J., De Boer S. H., 1997. The status of molecular biological research on the plant pathogenic genus Clavibacter // FEMS Microbiol. Lett. Vol. 150. P. 1-8.

63. Michelmore R. W., Meyers B. C., 1998. Clusters of resistance genes in plants evolve by divergent selection and a birth-and-death process // Genome Res. Vol. 8 . P. 1113-1130.

64. Minerdi D., Bianciotto V., Bonfante P., 2002. Endosymbiotic bacteria in mycorrhizal fungi: from their morphology to genomic sequences // Plant and Soil. Vol. 244. P. $211-219$.

65. Niehaus K., Albus U., Baier R., Schiene K. et al., 1998. Symbiotic suppression of the Medicago sativa plant defence system by Rhizobium meliloti oligosaccharides // Biological Nitrogen Fixation for 21 -th Century / Eds. C. Elmerich et al., Dordrecht, Boston, London: Kluwer Acad. Publ. P. 225-226.

66. Novak K., Skrdleta V., Kropacova M., Lisa L. et al., 1997. Interaction of two genes controlling symbiotic nodule number in pea (Pisum sativum L.) // Symbiosis. Vol. 23. P. 43-62.

67. O'Brian M.R., 1996. Heme synthesis in the Rhizobiumlegume symbiosis: a palette for bacterial and eukaryotic pigments // J. Bacteriol. Vol. 178. P. 2471-2478.

68. Ovtsyna A. O., Staehelin C., 2005. Bacterial signals required for the Rhizobium-legume symbiosis // Recent Res. Develop. Microbiol. Vol. 7. P. 631-648.

69. Phillips D. A., 1980. Efficiency of symbiotic nitrogen fixation in legumes // Annu. Rev. Plant Physiol. Vol. 31. P. 29-49.

70. Provorov N. A., Borisov A. Y., Tikhonovich I. A., 2002. Developmental genetics and evolution of symbiotic structures in nitrogen-fixing nodules and arbuscular mycorrhiza // J. Theor. Biol. Vol. 214. P. 215-232.

71. Provorov N. A., Tikhonovich I. A., 2003. Genetic resources for improving nitrogen fixation in legume-rhizobia symbiosis // Genet. Res. Crop Evolut. Vol. 50. P. 89-99.

72. Radutoiu S., Madsen L. H., Madsen E. B., Felle H. H. et al., 2003. Plant recognition of symbiotic bacteria requires two LysM receptor-like kinases // Nature. Vol. 425. P. 585-592. 
73. Rengel Z., 2002. Breeding for better symbiosis // Plant and Soil. Vol. 245. P. 147-162.

74. Riley I. T., Reardon T. B., 1995. Isolation and characterization of Clavibacter tritici associated with Anguina tritici in wheat from Western Australia // Plant Pathol. Vol. 44. P. 805-810.

75. Roth L. E., Stacey G., 1989. Bacterium release into host cells of nitrogen-fixing soybean nodules: the symbiosome membrane comes from three sources // Europ. J. Cell. Biol. Vol. 49. P. 13-23.

76. Santos R., Herouart D., Sigaud S., Touati D. et al., 2001. Oxidative burst in alfalfa - Sinorhizobium meliloti symbiotic interaction // Molec. Plant-Microbe Interact. Vol. 14. P. 86-89.

77. Schardl C. L., 2001. Epichloë festucae and related mutualistic symbionts of grasses // Fungal Genet. Biol. Vol. 33. P. 69-82.

78. Schardl C. L., Leuchtmann A., Chung K. R., Penny D. et al., 1997. Coevolution by common descent of fungal symbionts (Epichlö spp.) and grass hosts // Molec. Biol. Evol. Vol. 14. P. 133-143.

79. Schardl C. L., Leuchtmann A., Spiering M. J., 2004. Symbioses of grasses with seedborne fungal endophytes // Annu. Rev. Plant Biol. Vol. 55. P. 315-340.

80. Schußler A., 2002. Molecular phylogeny, taxonomy and evolution of Geosiphon pyriformis and arbuscular mycorrhizal fungi // Plant and Soil. Vol. 244. P. 75-83.

81. Sessitsch A., Howieson J. G., Perret X., Antoun H. et al., 2002. Advances in Rhizobium research // Crit. Rev. Plant Sci. Vol. 21. P. 323-378.

82. Smith S. E., Read D. J., 1997. Mycorrhizal Symbiosis ( second edition) - San Diego, London, New York, Boston, Sydney, Tokyo, Toronto: Academic Press, 560 p.

83. Spiering M. J., Moon C. D., Wilkinson H. H., Schardl C. L., 2005. Gene clusters for insecticidal loline alkaloids in the grass-endophyte fungus Neotyphodium uncinatum // Genetics. Vol. 169. P. 1403-1414.

84. Staehelin C., Charon C., Boller T., Crespi M. et al., 2001. Medicago truncatula plants overexpressing the early nodulin gene enod40 exhibit accelerated mycorrhizal colonization and enhanced formation of arbuscules // Proc. Natl. Acad. Sci. USA. Vol. 98. P. 15366-15371.

85. Tikhonovich I. A., Provorov N. A., 2007. Beneficial plant-microbe interactions // Comprehensive and Molecular Phytopathology / Eds. Y.T. Dyakov et al., Amsterdam: Elsevier, P. 365-420.

86. Tsyganov V. E., Morzhina E. V., Stefanov S. Y., Borisov A. Y. et al., 1998. New pea (Pisum sativum L.) genes sym 33 and sym40 control infection thread for- mation and root nodule function // Molec. Gen. Genet. Vol. 256. P. 491-503.

87. Tudzynski P., Scheffer J., 2004. Claviceps purpurea: molecular aspects of a unique pathogenic lifestyle // Molec. Plant Pathol. Vol. 5. P. 377-388.

88. Tunlid A., Talbot N. J., 2002. Genomics of parasitic and symbiotic fungi // Curr. Opin. Microbiol. Vol. 5. P. 513-519.

89. Vance C.P., 2001. Symbiotic nitrogen fixation and phosphorous acquisition. Plant nutrition in the world of declining renewable resources // Plant Physiol. Vol. 127. P. 390-397.

90. Vance C. P., Heichel G. H., 1991. Carbon dioxide assimilation in pulvini of Phaseolus vulgaris L. // Annu. Rev. Plant Physiol. Plant Molec. Biol. Vol. 42. P. 37-42.

91. White J. F., Sullivan R. F., Moy M., Meyer W. et al., 2002. Evolution of Epichloë/Neotyphodium endophytes and other Clavicipitacean biotrophs // Symbiosis: Mechanisms and Model Systems / Ed. J. Seckbach, Dordrecht, Boston, London: Kluwer Acad. Publ. P. 413-424.

\section{Молекулярные стратегии и сельскохозяйственное} использование растительно-микробных симбиозов

Тихонович Н. А., Проворов Н. А.

РЕЗЮМЕ: Рассматриваются молекулярные механизмы симбиотических взаимодействий между сельскохозяйственно-значимыми растениями и микроорганизмами, играющих важную роль в питании и защите растений. Такие симбиозы основаны на сигнальных взаимодействиях, приводящих к развитию новых тканевых/клеточных структур, а также к расширению метаболических возможностей у партнеров, что в значительной степени улучшает адаптивный потенциал растений вследствие устойчивости к биотическому или абиотическому стрессу. Данные, касающиеся молекулярных, генетических или экологических особенностей растительно-микробных взаимодействий, обеспечивают методологию создания устойчивых сельскохозяйственных культур, основанную на замещении химикатов (минеральных удобрений и пестицидов) микробиологическими препаратами. Усовершенствование растительно-микробных симбиозов должно включать согласованные изменения обоих партнеров, обеспечивающие создание комплементарных сочетаний их генотипов.

К КЛЮЧЕВЫЕ СЛОВА: полезные растительно-микробные взаимодействия, симбиотическая фиксация азота, арбускулярная микориза, клубеньковые бактерии, цианобактерии, спорыньевые грибы, эндофиты, биоконтроль патогенов и фитофагов, создание устойчивых растений 